\title{
OPTIMASI KERAPATAN ARUS DAN WAKTU ELEKTROLISIS DALAM PENGOLAHAN LIMBAH SURFAKTAN SECARA ELEKTROKOAGULASI Yusbarina, Buchari
}

\author{
Program Pendidikan Kimia, Fakultas Tarbiyah dan Keguruan, \\ Universitas Islam Negeri Sultan Syarif Kasim Riau, Indonesia \\ Program Studi Kimia, FMIPA, Institut Teknologi Bandung \\ Email: yusbarina_7@yahoo.com
}

\begin{abstract}
ABSTRAK
Elektrokoagulasi adalah metode pengolahan limbah cair yang keefektifannya sangat dipengaruhi oleh parameter operasionalnya. Oleh karena itu, tujuan dari penelitian ini adalah untuk optimasi parameter operasional yaitu kerapatan arus dan waktu elektrolisis dalam pengolahan limbah surfaktan secara elektrokoagulasi. Elektrokoagulasi dilakukan dengan sistem batch dengan menggunakan limbah simulasi sodium dodesil sulfat (SDS) pada kondisi operasional: konsentrasi SDS $200 \mathrm{mgL}^{-1}$, $\mathrm{pH}$ awal 4 dan tanpa penambahan elektrolit garam. Aluminium digunakan sebagai bahan elektroda. Variasi kerapatan arus adalah $25,50,75,100$ dan $150 \mathrm{~A} / \mathrm{m}^{2}$. Variasi waktu elektrolisis adalah 15, 30, 45 dan 60 menit. Pengolahan limbah surfaktan secara elektrokoagulasi efektif pada kerapatan arus $50 \mathrm{~A} / \mathrm{m}^{2}$ dengan waktu elektrolisis 60 menit dengan efisiensi penurunan kadar surfaktan sebesar $97,05 \%$.
\end{abstract}

Kata kunci: elektrokoagulasi, surfaktan anionik, kerapatan arus, waktu elektrolisis

\section{PENDAHULUAN}

Surfaktan merupakan nama lain dari surface active agent yang merupakan senyawa organik yang bersifat amphiphilic yaitu memiliki gugus polar yang suka air (hidrofilik) dan gugus non polar yang suka minyak (lipofilik) sekaligus dalam satu monomer. Surfaktan digunakan secara luas dalam berbagai industri dan kegiatan rumah tangga karena kemampuannya menurunkan tegangan antar muka fluida.

Penggunaan surfaktan meningkat dari hari ke hari. Berbagai industri seperti industri deterjen, produk kebersihan dan kecantikan menggunakan surfaktan anionik sebagai bahan baku utama. Oleh karena itu dibutuhkan satu metode yang handal dan ekonomis untuk mengolah limbahnya sebelum dibuang atau dilepas ke sumber air.

Menurut Mollah dkk, (2001), Elektrokoagulasi (EC) memiliki begitu banyak keuntungan dalam pengolahan limbah cair, diantaranya:

1. EC membutuhkan peralatan yang sederhana dan mudah dioperasikan.

2. Air limbah yang diolah dengan EC menjadi air yang jernih, tidak berwarna dan tidak berbau.

3. Lumpur yang dihasilkan EC relatif stabil dan mudah untuk dipisahkan, karena terutama berasal dari oksida logam. Selain itu lumpur yang dihasilkan sedikit.

4. Flok yang terbentuk pada elektrokoagulasi memiliki kesamaan dengan flok yang berasal dari koagulasi kimia. Perbedaannya adalah flok dari elektrokoagukasi berukuran lebih besar dengan kandungan air yang sedikit, lebih stabil dan mudah dipisahkan secara cepat dengan filtrasi. 
5. Elektrokoagulasi menghasilkan effluen dengan nilai TDS yang lebih kecil jika dibandingkan dengan pengolahan kimiawi. Jika air ini digunakan kembali, kandungan TDS yang rendah akan mengurangi biaya recovery.

6. Proses elektrokoagulasi memiliki keuntungan dalam mengolah partikel koloid yang berukuran sangat kecil karena dengan pemakaian arus listrik menyebabkan proses koagulasi lebih mudah terjadi dan lebih cepat.

7. Proses elektrokoagulasi mencegah penggunaan bahan kimia sehingga tidak bermasalah dengan netralisasi kelebihan bahan kimia dan tidak membutuhkan kemungkinan pengolahan berikutnya jika terjadi penambahan konsentrasi bahan kimia yang terlalu tinggi seperti pada penggunaan bahan kimia.

8. Gelembung gas yang dihasilkan selama elektrolisis dapat membawa polutan ke atas permukaan sehingga flok tersebut dapat dengan mudah terkonsentrasi, dikumpulkan dan dipisahkan.

9. Proses elektrolisis pada sel elektrokoagulasi dikontrol dengan pemakaian listrik tanpa perlu memindahkan bagian di dalamnya, sehingga membutuhkan perawatan yang sedikit.

10. Teknik elektrokoagulasi dapat dengan mudah diaplikasikan di daerah yang tidak terjangkau layanan listrik yakni dengan menggunakan panel matahari yang cukup untuk terjadinya proses pengolahan.

Elektrokoagulasi telah banyak digunakan untuk mengolah berbagai jenis limbah, diantaranya penghilangan warna pada limbah pabrik teh (Maghanga, J.K dkk, 2009), pengolahan limbah tekstil (Kobya, M dkk, 2003), pengolahan limbah zat warna (Mollah, M.Y.A dkk, 2010, Alaton, I.A dkk
2008, Kashefialasl, M dkk, 2006), pemurnian air laut (Timmes, T.C, 2009), penghilangan hidrokuinon dari air (Prabhakari, D dkk, 2010), dan penghilangan logam - logam berat di perairan (Vasudevan, S, 2009).

Keefektifan elektrokoagulasi sangat dipengaruhi oleh parameter operasional, yaitu $\mathrm{pH}$ awal, penambahan elektrolit garam, kerapatan arus, waktu elektrolisis dan konsentrasi awal surfaktan anionik. Pada penelitian ini, parameter yang dioptimasi adalah kerapatan arus dan waktu elektrolisis.

Pengaturan kerapatan arus sangat penting dalam proses elektrokoagulasi. Kerapatan arus sangat mempengaruhi kecepatan elektrolisis logam anoda dan produksi gelembung secara elektrolitik.

Rapat arus (I) didefinisikan sebagai arus (i) yang mengalir pada elektroda dengan luas permukaan (s) dari elektroda. Jika dimensi arus adalah amper dan luas permukaan elektroda adalah $\mathrm{cm}^{-2}$, maka dimensi rapat arus adalah amper $/ \mathrm{cm}^{2}$. Karena reaksi elektrolisis dapat berlangsung pada anoda dan katoda maka rapat aruspun dinyatakan pula sebagai rapat arus anoda dan rapat arus katoda.

Pada proses elektrokoagulasi ini, pada anoda aluminium terjadi reaksi oksidasi aluminium menghasilkan ion $\mathrm{Al}^{3+}$. Rapat arus anoda $\left(\mathrm{I}_{\mathrm{A}}\right)$ merupakan laju reaksi oksidasi $\mathrm{Al}$ menjadi $\mathrm{Al}^{3+}$ yang terjadi pada permukaan anoda dengan luas tertentu. Sementara itu pada katoda reaksi yang terjadi adalah $2 \mathrm{H}_{2} \mathrm{O}+2 \mathrm{e} \rightarrow \mathrm{H}_{2}+2 \mathrm{OH}^{-}$. Secara fisik rapat arus katoda diartikan laju pembentukan gas $\mathrm{H}_{2}$ yang terjadi pada permukaan katoda dengan luas tertentu.

Di bidang industri, penggunaan rapat arus lebih disukai daripada penggunaan arus, terutama di bidang industri pelapisan secara listrik (electroplating), dan industri 
pengolahan

hasil

tambang

(electrometallurgy). Sedangkan penggunaan arus lebih banyak di bidang analisis, seperti pada elektrogravimetri, coulometri dan voltametri.

Waktu elektrolisis sangat menentukan jumlah $\mathrm{Al}^{3+}$ yang ada di larutan. Optimasi waktu dimaksudkan untuk mencari kondisi dimana \% penurunan kadar surfaktan SDS tinggi dan kadar $\mathrm{Al}^{3+}$ di larutan sekecil mungkin

\section{METODOLOGI PENELITIAN}

\section{Alat}

Alat yang digunakan pada penelitian ini adalah peralatan gelas yang lazim digunakan di laboratorium penelitian kimia analitik, sumber arus listrik searah, voltmeter (multimeter), amperemeter (multimeter), pH-meter, konduktometer, pengaduk magnetik, batang pengaduk magnetik, neraca analitis Mettler AE 200, spektrofotometer UV-Vis Agilent, spektrofotometer serapan atom SpectrAA (PPPGL-Bandung).

\section{Bahan}

Bahan yang digunakan pada penelitian ini adalah sodium dodesil sulfat (SDS), lempeng aluminium (95,6\%), aquades, indikator fenolftalin, $\mathrm{NaOH}, \mathrm{H}_{2} \mathrm{SO}_{4(\mathrm{p})}$, Metilen biru, $\mathrm{CHCl}_{3}$ p.a., $\mathrm{HCl}_{(\mathrm{p})}, \mathrm{HNO}_{3(\mathrm{p})}$, $\mathrm{Al}_{2} \mathrm{O}_{3}$.

\section{Prosedur Kerja \\ Reaktor}

Pengoperasian dilakukan dengan sistem batch. Reaktor elektrokoagulasi yang digunakan berkapasitas $500 \mathrm{~mL}$ yang dilengkapi dengan peralatan stirrer untuk mengaduk larutan agar konsentrasi koagulan menjadi homogen. Elektroda yang digunakan sebagai anoda dan katoda adalah ukuran $4 \mathrm{~cm}$ x $7 \mathrm{~cm}$ sebanyak dua buah. Luas permukaan elektroda anoda pada penelitian ini adalah $0.0028 \mathrm{~m}^{2}$ sehingga diperoleh rasio luas permukaan elektroda anoda terhadap volume reaktor sebesar 5.6 $\mathrm{m}^{2} / \mathrm{m}^{3}$. plat aluminium ( $\left.95,6 \%\right)$ dengan Jarak antar elektroda adalah $9 \mathrm{~mm}$. Pada Penelitian ini semua elektroda dihubungkan dengan arus listrik yang berasal dari arus DC, yaitu satu elektroda dihubungkan dengan kutub positif yaitu anoda dan satu elektroda dengan kutub negatif yaitu katoda.

Optimasi kerapatan arus dan waktu eketrolisis pada elektrokoagulasi

Untuk mengoptimasi kerapatan arus dan waktu elektrolisis maka dilakukan variasi pada $25,50,75,100$, dan $150 \mathrm{~A} / \mathrm{m}^{2}$. Pada setiap kerapatan arus dilakukan pengambilan sampel setiap 15, 30, 45, dan 60 menit. Parameter yang lain dibuat tetap yaitu konsentrasi $\operatorname{SDS}=200 \mathrm{mg} / \mathrm{L}, \mathrm{pH}$ awal 4, dan tanpa penambahan elektrolit. Kemudian dimonitor penurunan kadar SDS setiap sampel dengan spektrofotometer secara biru metilen dan dihitung konsumsi energi.

\section{Pengujian surfaktan anionik}

Pada penelitian ini monitoring kadar surfaktan anionik dilakukan dengan spektrofotometer secara biru metilen yang mengacu pada SNI 06-6989.51-2005. Prinsip utama metode pengujian ini adalah surfaktan anionik akan bereaksi dengan metilen biru membentuk pasangan ion berwarna biru yang larut dalam pelarut organik. Intensitas warna biru yang terbentuk diukur dengan spektrofotometer pada panjang gelombang $652 \mathrm{~nm}$. Serapan yang diukur setara dengan kadar surfaktan anionik.

\section{HASIL DAN PEMBAHASAN}

Pengaruh kerapatan arus dan waktu elektrolisis terhadap efektivitas elektrokoagulasi surfaktan anionik

Kerapatan arus adalah arus yang dialirkan ke elektroda dibagi dengan luas permukaan elektroda. Kerapatan arus sangat 
mempengaruhi kecepatan elektrolisis logam anoda dan produksi gelembung secara elektrolitik (Ankit Mohta, 2007). Menurut Malakootian, M. dkk, (2009) dengan meningkatnya arus listrik, efisiensi semakin besar. Pada potensial yang tinggi, ukuran dan kecepatan terbentuknya flok meningkat, sehingga semakin efektif proses elektrokoagulasi.

Pada kerapatan arus yang tinggi, pelarutan aluminium di anoda meningkat, menghasilkan jumlah $\mathrm{Al}^{3+}$ dan $\mathrm{Al}(\mathrm{OH})_{\mathrm{n}(\mathrm{s})}$ yang lebih banyak. Meningkatnya konsentrasi $\mathrm{Al}^{3+}$ dapat meningkatkan reaksi netralisasi muatan kontaminan membentuk flok. Selain itu, dengan meningkatnya kerapatan arus, kecepatan terbentuknya gelembung gas hidrogen di katoda meningkat dan ukuran gelembung gas hidrogen yang dihasilkan kecil. Gelembung yang lebih kecil memberi area permukaan yang lebih besar untuk mengikat partikel di larutan sehingga menghasilkan efisiensi pemisahan yang lebih baik.

Waktu elektrolisis sangat menentukan jumlah $\mathrm{Al}^{3+}$ yang ada di larutan. Optimasi waktu dimaksudkan untuk mencari kondisi dimana \% penurunan kadar surfaktan SDS tinggi dan kadar $\mathrm{Al}^{3+}$ di larutan sekecil mungkin.

Variasi kerapatan arus yaitu $25,50,75$, 100 dan $150 \mathrm{~A} / \mathrm{m}^{2}$ dimonitor penurunan kadar SDS pada menit ke 15, 30, 45 dan 60. Hasilnya dapat dilihat pada tabel dan grafik di bawah ini:

Tabel 1. Hasil \% penurunan kadar surfaktan pada variasi kerapatan arus dan waktu elektrolisis

\begin{tabular}{ccccc}
\hline $\begin{array}{c}\text { Kerapatan } \\
\text { Arus }\end{array}$ & \multicolumn{4}{c}{ \% penurunan kadar surfaktan pada } \\
menit ke \\
$\left(\mathrm{A} / \mathrm{m}^{2}\right)$ & 15 & 30 & 45 & 60 \\
\hline 25 & 79.89 & 91.49 & 91.9 & 93.58 \\
$\mathbf{5 0}$ & 84.12 & 89.25 & 95.94 & $\mathbf{9 7 . 0 5}$ \\
75 & 81.88 & 94.72 & 95.78 & 95.76 \\
100 & 83.19 & 91.68 & 81.24 & 93.19 \\
150 & 88.26 & 94.05 & 94.79 & 95.07 \\
\hline
\end{tabular}

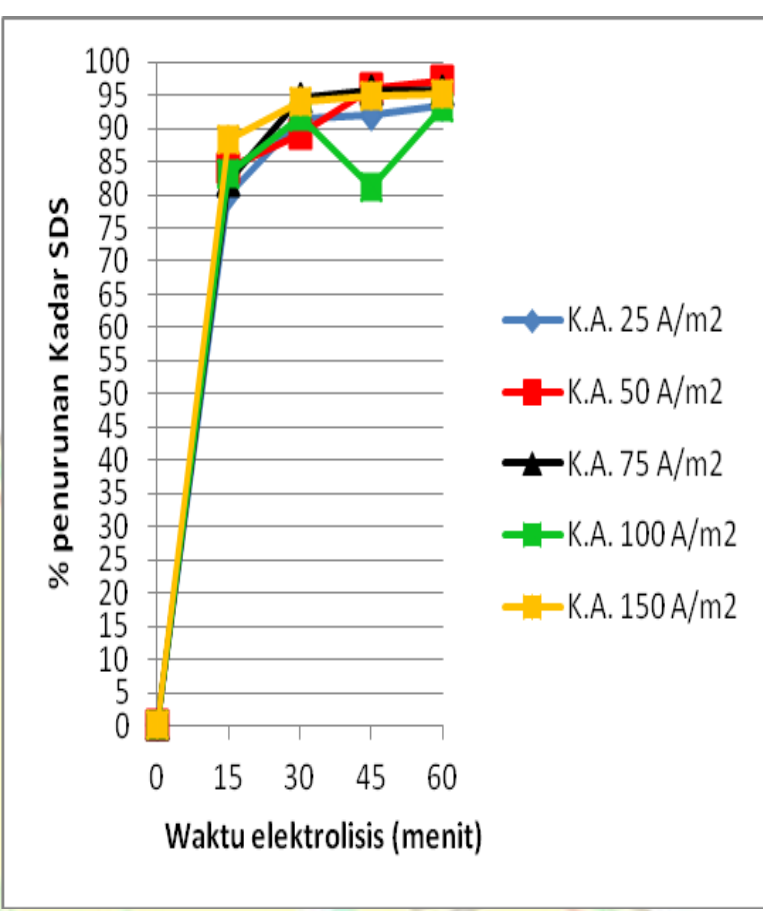

Gambar 1.

Hasil \% penurunan kadar surfaktan dengan variasi kerapatan arus yaitu 25, 50, 75, 100 dan $150 \mathrm{~A} / \mathrm{m}^{2}$ dimonitor menit ke 15, 30, 45 dan 60 .

Kerapatan arus $50 \mathrm{~A} / \mathrm{m}^{2}$ dengan waktu elektrolisis 60 menit memberikan efektivitas yang paling tinggi. Di bawah dan di atas kerapatan arus ini memberikan efektivitas yang kurang baik. Dengan meningkatnya potensial listrik jumlah aluminium yang dioksidasi meningkat dan menyebabkan efektivitas meningkat. Tetapi kerapatan arus yang terlalu besar menyebabkan tidak ada waktu untuk pembentukan flok, sehingga efektivitas menurun.

\section{KESIMPULAN}

Pengolahan limbah surfaktan secara elektrokoagulasi efektif pada kerapatan arus $50 \mathrm{~A} / \mathrm{m}^{2}$ dengan waktu elektrolisis 60 menit dengan efisiensi penurunan kadar surfaktan sebesar $97,05 \%$.

\section{DAFTAR PUSTAKA}

Alaton, I.A., Kabdasli I., dan Sahin, Y. (2008): Effect of Operating Parameters on the Electrocoagulation of Simulated 
Acid Dyebath Effluent, Open Environ. Biol. Monit. J. 1, 1-7

Kashefialasl, M., Khosravi, M., Marandi, R., dan Seyyedi, K. (2006): Treatment of dye solution containing colored index acid yellow 36 by electrocoagulation using iron electrodes, Int. J. Environ. Sci. Technol. Vol. 2, No. 4, 365-371

Kobya, M., Can, O.T., dan Bayramoglu, M., (2003): Treatment of textile wastewaters byelectrocoagulation using iron andaluminum electrodes, $J$. Hazard. Mater. B100, 163-178

Maghanga, J.K., Segor, F.K., Etiégni, L., dan Lusweti, J. (2009): Electrocoagulation method for colour removal in tea effluent: a case study of chemoni tea factory in rift valley, Bull. Chem. Soc. Ethiop, 23(3), 371-381

Mohta, A. (2007): Electro-chemical Treatment of Wastewater, Master of Technology Disertation, Thapar University, $21-22$

Mollah, M.Y.A., Schennach, R., Parga, J.R., dan Cocke, D.L. (2001): Electrocoagulation (EC) - science and applications, J. Hazard. Mater. 84, 29 41

Mollah, M.Y.A., Morkovsky, P., Gomes, J.A.G., Kesmez, M., Parga, J., dan Cocke, D.L. (2004): Fundamentals, present and future perspectives of electrocoagulation, J. Hazard. Mater. 114, 199-210

Mollah, M.Y.A., Gomes, J.A.G., Das, K.K., dan Cocke, D.L. (2010): Electrochemical treatment of Orange II dye solution-Use of aluminum sacrificial electrodes and floc characterization, J. Hazard. Mater. 174, 851-858

Prabhakari, D., Basha, C.A., Kannadasan T., dan Aravinthan P. (2010): Removal of hydroquinone from water by electrocoagulation using flow cell and optimization by response surface methodology. J. Environ. Sci. Health., Part A, 45, 400-412

SNI 06-6989.34-2005. Air dan Air Limbahbagian 34: Cara Uji Kadar Aluminium (Al) dengan Spektrofotometer Serapan Atom.

SNI 06-6989.51-2005. Air dan Air Limbahbagian 51: Cara Uji Kadar Surfaktan Anionik dengan Spektrofotometer Secara Biru Metilen.

Timmes, T.C., Chul Kim, H., dan Dempsey, B.A. (2009): Electrocoagulation pretreatment of seawater prior to ultrafiltration: Bench-scale applications for military water purification systems, Desalination, 249, 895-901

Vasudevan, S., Jayaraj, J., Lakshmi, J., dan Sozh, G. (2009): Removal of iron from drinking water by electrocoagulation: Adsorption and kinetics studies, Korean J. Chem. Eng., 26(4), 1058106 